\title{
PENGARUH KAPASITAS FISKAL DAN RESTRUKTURISASI PINJAMAN TERHADAP KINERJA PEMBAYARAN PINJAMAN PEMERINTAH DAERAH
}

\author{
Bramiana Cahya Surya \\ Kantor Wilayah Ditjen Perbendaharaan Provinsi Maluku Utara \\ bcahyasurya@gmail.com
}

\section{INFORMASI ARTIKEL}

Diterima Pertama

7 Juni 2016

Dinyatakan Diterima

11 November 2016

KATA KUNCI:

Fiscal Capacity, Debt Restructuring, Local Government Debt Repayment Performance.

KLASIFIKASI JEL:

H30, H74.

\begin{abstract}
ABSTRAK
This study analyzes the effect of Fiscal Capacity Factors, namely Local Government Revenues (PAD), Personnel Expenses, General Allocation Fund (DAU), Shared Revenues from Central Government (DBH), Other Local Revenues (LP), Poverty Level and Debt Restructuring Policy against Local Government Debt Repayment Performance. Partial Least Square (PLS) method is used to analyze pooled data from 2003 to 2013 to compare the condition of loan performance five years before and five years after the debt restructuring policy of 2008. Panel data consisted of 45 Local Governments following debt restructuring policy. The results show that the Fiscal Capacity Factors and Debt Restructuring Policy simultaneously have significant effects on the Local Government Debt Repayments Performance. On the other hand, fiscal capacity factors, namely PAD, DBH, LP and BP (partially), have a significant effect on the Local Government Debt Repayment Performance, while DAU and poverty level have no affect on Local Government Debt Repayment Performance. The determinant value of $R^{2}=0,469$ indicates the relationship between dependent and independent variables, explaining 46,9\% of the models, while the remaining $53,1 \%$ is contributed by other variables not explained in this study.
\end{abstract}

Penelitian ini bertujuan untuk mengetahui pengaruh faktor-faktor Kapasitas Fiskal yaitu Pendapatan Asli Daerah (PAD), Belanja Pegawai (BP), Dana Alokasi Umum (DAU), Dana Bagi Hasil (DBH), Lain-lain Pendapatan yang Sah (LP), Kemiskinan dan Restrukturisasi Pinjaman terhadap Kinerja Pembayaran Pinjaman Pemerintah Daerah. Teknik analisis dengan Partial Least Square (PLS) menggunakan data panel dari tahun 2003 sampai dengan 2013. Pemilihan data dimaksudkan untuk membandingkan kondisi pinjaman 5 tahun sebelum dan 5 tahun sesudah restrukturisasi pinjaman, dimana kebijakan restrukturisasi pinjaman diimplementasikan tahun 2008. Data panel terdiri dari 45 Kabupaten/ Kota yang memiliki pinjaman dalam restrukturisasi. Hasil penelitian menunjukkan bahwa Kapasitas Fiskal dan Restrukturisasi Pinjaman secara simultan berpengaruh signifikan terhadap Kinerja Pembayaran Pinjaman Pemerintah Daerah. Secara parsial faktor-faktor Kapasitas Fiskal menunjukkan bahwa PAD, DBH, LP, dan BP berpengaruh signifikan terhadap Kinerja Pembayaran Pinjaman sedangkan DAU dan Kemiskinan tidak berpengaruh terhadap Kinerja Pembayaran Pinjaman. Nilai determinan $R^{2}=0,469$ menunjukkan bahwa hubungan variabel dependen dan independen dalam penelitian ini hanya dapat menjelaskan sebesar $46,9 \%$, sedangkan sisanya sebesar $53,1 \%$ merupakan kontribusi dari variabel lain yang tidak dibahas dalam penelitian ini. 


\section{PENDAHULUAN}

Pinjaman daerah di Indonesia telah ada sejak tahun 1978. Namun perkembangan posisi pinjaman daerah di Indonesia menunjukkan tren yang kurang baik hingga tahun 2008. Lewis (2003) meneliti seluruh Pinjaman Daerah yang disalurkan ke Pemerintah Daerah maupun Badan Usaha Milik Daerah (BUMD). ${ }^{1}$ Kumulatif penarikan pinjaman daerah tahun 1978 sampai dengan 1999 sebesar Rp4.599.864 juta dengan kumulatif tunggakan sebesar Rp843.269 juta (18,3 persen dari penarikan). Khusus pinjaman Pemerintah Daerah, dari 307 perjanjian pinjaman, 269 perjanjian pinjaman default. Total tunggakan pinjaman Pemerintah Daerah sampai tahun 1999 mencapai Rp221.021 juta (32,23 persen dari penarikan pinjaman).

Elmi (2002) dengan data pinjaman tahun 2000 dan 2001 membandingkan tingkat tunggakan pinjaman Perusahaan Daerah Air Minum (PDAM) dan Pemerintah Daerah pada 7 provinsi di Indonesia, menunjukkan bahwa kumulatif tunggakan pinjaman Pemerintah Daerah tertinggi ada di Provinsi Sumatera Barat sebesar Rp9.897,79 juta (51,93 persen dari pinjaman), kemudian Provinsi Jawa Barat sebesar Rp29.347,01 juta (37,97 persen dari pinjaman) dan tunggakan pinjaman terendah di Provinsi D.I. Yogyakarta sebesar Rp580,55 juta (2,39 persen dari pinjaman).

Sampai tahun 2006 jumlah penarikan pinjaman daerah mencapai Rp3,065 triliun dengan jumlah kewajiban pokok yang telah jatuh tempo sebesar Rp1,992 triliun dan kewajiban non pokok sebesar Rp2,981 triliun. Nilai kumulatif pembayaran kewajiban pokok dan non pokok sampai tahun 2006 mencapai Rp3,563 triliun. Jumlah tunggakan kewajiban keseluruhan tahun 2006 adalah Rp1,410 triliun. Jika nilai tunggakan dibandingkan dengan jumlah penarikan sampai tahun 2006 maka nilai tunggakan telah mencapai 45,99 persen.

Pada tahun 2008, untuk menghindari semakin banyaknya Pemerintah Daerah yang mengalami default, Pemerintah Pusat membuat kebijakan untuk melaksanakan restrukturisasi pinjaman Pemerintah Daerah. Restrukturisasi pinjaman jangka panjang Pemerintah Daerah dilakukan dengan cara cut off posisi tunggakan pinjaman per 22 Oktober 2008, sesuai dengan tanggal ditetapkan Peraturan Menteri Keuangan

1 Blane D. Lewis, Local Borrowing and Repayment in Indonesia: Does Fiscal Capacity Matter. Jurnal of World Development, 2003, Vol.31, No.6, hlm.1047-1063.
Nomor 153/PMK.07/2008 tentang Penyelesaian Pinjaman Negara yang Bersumber dari Penerusan Pinjaman Luar Negeri, Rekening Dana Investasi, dan Rekening Pembangunan Daerah pada Pemerintah Daerah.

Penelitian terdahulu mengenai pinjaman daerah sangat penting untuk mengetahui track record pemerintah daerah dalam penyelesaian kewajiban atas pinjaman daerah maupun dalam pengelolaan keuangan daerahnya. Sejak tahun 2005, penelitian-penelitian di Indonesia hanya melihat kelayakan Pemerintah Daerah dalam perencanaan pinjaman. Penelitian Wulandari (2007), Pasaribu (2008), Sitorus (2009), Tallesang (2009) menganalisis rasio kemampuan keuangan Pemerintah Daerah untuk mengembalikan pinjaman (Debt Service Coverage Ratio — DSCR) dengan menghitung nilai DSCR paling sedikit 2,5 dan menentukan Batas Maksimum Pinjaman (BMP) serta jangka waktu pinjaman Pemerintah Daerah.

Taufikkurrohman (2009) meneliti tentang pengaruh pendapatan perkapita, surplus anggaran, belanja modal, PAD, DAU, pertumbuhan ekonomi dan faktor politik terhadap pinjaman daerah pada kabupaten/ kota di Provinsi Jawa Timur. Dengan menggunakan analisis regresi berganda, hasil penelitiannya menemukan bukti positif bahwa pendapatan perkapita, surplus anggaran belanja modal, PAD, DAU, pertumbuhan ekonomi berpengaruh dalam melakukan pinjaman daerah. Mulyono (2007) meneliti tentang pengaruh pendapatan per kapita, jumlah penduduk, pertumbuhan ekonomi, PAD, transfer Pemerintah Pusat (DAU), belanja modal, dan surplus/ defisit anggaran non keuangan terhadap pinjaman daerah pada kabupaten/kota di Provinsi Jawa Timur. Dengan analisis regresi data panel menggunakan sampel 21 kabupaten/ kota yang memiliki pinjaman, diperoleh bukti positif bahwa pendapatan per kapita, jumlah penduduk, pertumbuhan ekonomi, PAD, transfer Pemerintah Pusat (DAU), belanja modal, dan surplus/ defisit anggaran non keuangan berpengaruh terhadap pinjaman daerah.

Penelitian Hita, et al. (2009) menganalisis pengaruh belanja modal, tingkat rasio pinjaman, kapasitas keuangan, pendapatan usaha daerah terhadap perubahan pinjaman daerah pada kota Navarra di Spanyol. Hasil penelitiannya diperoleh bukti positif bahwa belanja modal, tingkat rasio pinjaman, kapasitas keuangan, pendapatan usaha daerah mempengaruhi perubahan pinjaman daerah. Di Navarra pendapatan dari pembangunan perkotaan yang dibiayai dari pinjaman mengalami peningkatan, menggantikan sumber-sumber lain seperti perpajakan biasa dan hibah. 
Aribawa (2005) meneliti kapasitas daerah dalam pengembalian pinjaman, yang secara deskriptif menjelaskan kontribusi PAD, Dana Bagi Hasil, Dana Alokasi Umum, dan belanja daerah dengan menggunakan analisis keuangan (DSCR). Hasil penelitiannya menunjukkan bahwa Pemerintah Kota Semarang memiliki kemampuan untuk melakukan pinjaman. Sebelumnya Pemerintah Kota Semarang telah memperoleh pinjaman dari Bank Dunia untuk program peningkatan pelayanan prasarana perkotaan meliputi 6 sektor meliputi jalan kota, air bersih, drainase, sanitasi, persampahan, perbaikan kampung dan pasar. Program pembangunan ini bernilai positif terhadap pertumbuhan penerimaan daerah.

Pascual (2004) meneliti pengaruh faktor sosial ekonomi (pendapatan, hibah), politik (siklus pemilihan umum) dan anggaran (investasi, penerimaan bruto, obligasi) terhadap motivasi pinjaman Pemerintah Daerah di Spanyol dengan data panel yang meliputi 100 Pemerintah Daerah yang memiliki populasi lebih dari 50.000 penduduk periode tahun 1992-1999. Hasil penelitiannya menemukan hubungan positif faktor sosio-ekonomi dan anggaran terhadap motivasi pinjaman daerah.

Penelitian Lewis (2003) menunjukkan bahwa faktor-faktor kapasitas fiskal yang berasal dari surplus operasi berpengaruh terhadap kinerja pembayaran pinjaman Pemerintah Daerah. Penelitian ini diperkuat dengan penelitian dari Vazquez (1997) ${ }^{2}$ dan Nagowski (2007) ${ }^{3}$ bahwa kapasitas fiskal dapat meningkatkan pendapatan dari sumber-sumber mereka sendiri dalam rangka membayar kebutuhan pelayanan standar barang dan jasa.

Penelitian terdahulu terkait restrukturisasi pinjaman Pemerintah Daerah masih sangat terbatas. Penelitian Manoel, et al. dalam Canuto dan Liu (2013) menjelaskan restrukturisasi pinjaman daerah di Brazil dilaksanakan dalam 3 tahap: tahap pertama difokuskan pada perubahan ketentuan pembayaran utang, tahap kedua menstabilkan situasi ekonomi makro dan membuat Pemerintah Daerah lebih efisien (mengurangi peran negara menuju pasar terbuka), tahap ketiga konsolidasi penyesuaian

2 J. Martinez Vazquez dan L.F Jameson Boex, Fiscal Capacity: An Overview of concepts and Measurement Issues and Thei Applicability in the Russian Federation. Working Paper. 1997, No. 97-3.

3 Peter Nagowski, The Fiscal Capacity of New England. Policy Brief 07-4, 2007, New England Public Policy Center, Federal Reserve Bank of Boston. fiskal dengan diberlakukannya Peraturan Tanggung Jawab Fiskal (Fiscal Responsibility Law FRL). ${ }^{4}$ Restrukturisasi di Brazil terbukti mampu menjaga stabilitas ekonomi makro dan mengurangi tingkat utang Pemerintah Daerah.

Mengingat hingga saat ini penelitian mengenai pinjaman daerah masih sangat terbatas dan penelitian mengenai hubungan restrukturisasi terhadap pinjaman pemerintah daerah di Indonesia belum ada, maka penelitian ini difokuskan untuk mengetahui pengaruh Kapasitas Fiskal dan Restrukturisasi Pinjaman terhadap kinerja pembayaran pinjaman Pemerintah Daerah, serta untuk mengetahui hubungan kemampuan Pemerintah Daerah dalam mengembalikan pinjamannya (Debt Service Coverage Ratio - DSCR) terhadap kinerja pembayaran pinjaman Pemerintah Daerah.

Penelitian ini merupakan replikasi penelitian yang dilakukan oleh Lewis (2003). Perbedaannya terletak pada: waktu, dan objek penelitian, serta penambahan variabel restrukturisasi pinjaman. Selain itu Lewis (2003) menguji kapasitas fiskal dengan pinjaman Pemerintah Daerah dan BUMD, sementara penelitian ini hanya menguji pinjaman Pemerintah Daerah setelah adanya restrukturisasi dan tidak memasukkan data BUMD karena memiliki indikator penanganan yang berbeda. Dengan demikian penelitian ini akan menganalisis pengaruh kapasitas fiskal daerah dan restrukturisasi pinjaman daerah terhadap kinerja pembayaran pinjaman Pemerintah Daerah.

\section{KERANGKA TEORI DAN PENGEM- BANGAN HIPOTESIS}

\subsection{Kinerja Pembayaran Pinjaman Daerah}

Menurut Undang-undang Nomor 32 Tahun 2004, pinjaman daerah adalah semua transaksi yang mengakibatkan daerah menerima sejumlah uang atau menerima manfaat yang bernilai uang dari pihak lain sehingga daerah tersebut dibebani kewajiban untuk membayar kembali. Pinjaman daerah bertujuan memperoleh sumber pembiayaan dalam rangka penyelenggaraan urusan Pemerintahan Daerah. Pemerintah Daerah dapat melakukan pinjaman yang bersumber dari Pemerintah Pusat, Pemerintah Daerah lain, lembaga keuangan bank, lembaga keuangan bukan bank, dan masyarakat. Untuk menjaga kinerja pembayaran pinjaman, sesuai Bab III, pasal 15, Peraturan Pemerintah Nomor 30 Tahun 2011 persyaratan pinjaman dari Pemerintah Pusat adalah sebagai berikut:

4 Otaviano Canuto dan Lili Liu, Until Debt Do Us Part: Subnational Debt, Insolvency, and Markets. The World Bank, 2013. 
- Jumlah sisa pinjaman Pemerintah Daerah ditambah jumlah pinjaman yang akan ditarik tidak melebihi 75 persen dari jumlah penerimaan umum APBD tahun sebelumnya.

- Rasio kemampuan keuangan Pemerintah Daerah untuk mengembalikan pinjaman (Debt Service Coverage Ratio - DSCR) paling sedikit 2,5 dengan memperhatikan perkembangan perekonomian nasional dan kapasitas fiskal daerah. DSCR dihitung dengan formula sebagai berikut:

$$
D S C R=\frac{\{P A D+D A U+(D B H-D B H D R)\}-B W}{\text { Pokok Pinjaman }+ \text { Bunga }+B L}
$$

DSCR

$$
\begin{array}{lr}
=\text { Rasio } & \text { Kemampuan } \\
\text { Membayar } & \text { Kembali }
\end{array}
$$$$
\text { Pinjaman Daerah yang }
$$$$
\text { bersangkutan; }
$$

PAD = Pendapatan Asli Daerah;

DAU = Dana Alokasi Umum;

DBH = Dana Bagi Hasil;

DBHDR = Dana Bagi Hasil Dana

Reboisasi;

BW = Belanja Wajib terdiri dari

Belanja pegawai dan belanja anggota dewan;

Pokok Pinjaman = Angsuran Pokok Pinjaman;

Bunga $\quad=$ Beban Bunga Pinjaman;

BL = Biaya Lain.

- Tidak mempunyai tunggakan atas pengembalian pinjaman yang berasal dari Pemerintah.

- Pinjaman Pemerintah Daerah dilakukan dengan persetujuan DPRD.

Metode Pemerintah Daerah dalam membiayai belanja modal daerah secara garis besar terdiri dari 2 tahap: pertama, pilihan pembiayaan apakah melalui pinjaman ataupun pajak ditentukan oleh pejabat pemerintah daerah. Kedua, anggota Dewan Perwakilan Rakyat Daerah memilih tingkat belanja modal publik. Pemerintah pusat memiliki peran utama sebagai supervisi peminjaman dan praktek penganggaran daerah (Marks dan Raman, 2007). Capeci (1994) meneliti hubungan antara kebijakan fiskal Pemerintah Daerah dan biaya pinjaman dengan menggunakan sampel dari kota New Jersey menunjukkan hasil yang konsisten dengan pandangan bahwa keputusan fiskal periode berjalan yang dilakukan berdampak pada biaya pinjaman. ${ }^{5}$

Teori federalisme fiskal menunjukkan bahwa dalam kasus-kasus tertentu lebih baik untuk

5 John Capeci, Local Fiscal Policies, Default Risk, and Municipal Borrowing Cost, Journal of Public Economics, 1994, Vol. 53, hlm. 73-89. membiayai proyek investasi dari pinjaman dibandingkan dari pendapatan asli daerah saat ini (King, 1984 dalam Swianiewicz, 2004). ${ }^{6}$ Mendukung Teori Federalisme Fiskal, Alm dan Indrawati (2003) menyatakan bahwa sesuai "prinsip subsidiaritas", Pemerintah Daerah dapat menggunakan pinjaman. Biaya proyek-proyek investasi melalui pendapatan dari generasi sekarang cenderung tidak adil dan tidak efisien, karena generasi mendatang akan mendapatkan keuntungan dari proyek-proyek berumur panjang. Menurut Gibbon (1928) pinjaman dapat dilakukan dengan mempertimbangkan: 1) Beban pinjaman akan diberikan kepada periode masa manfaat hasil pekerjaan belanja modal. 2) Beberapa perhitungan pinjaman harus diambil dari kemungkinan permintaan masyarakat di masa depan untuk layanan baru, atau untuk meningkatkan layanan yang sudah ada, dan karena itu, beban tidak boleh sembarangan dikenakan dalam jangka waktu yang panjang. 3) Pinjaman sekarang harus lebih berhati-hati karena akan semakin besar beban pembayar pajak yang harus menanggung sehubungan komitmen pinjaman. 4) Risiko adanya pasang surut masyarakat sehingga harus bijaksana dalam menentukan periode pinjaman tidak boleh terlalu lama, dibayar hanya untuk masa manfaat pekerjaan belanja modal itu sendiri. ${ }^{7}$ Risiko ini lebih besar dalam beberapa jenis masyarakat.

Oplotnik dan Brezovnik (2004) berpendapat bahwa Pemerintah Daerah hanya dapat meminjam atas persetujuan dari Kementerian Keuangan untuk menerbitkan surat berharga dan memperoleh pinjaman. ${ }^{8}$ Musgrave (1959) dalam Swianiewicz (2004) berpendapat bahwa pinjaman daerah diperbolehkan untuk belanja modal (proyek) tetapi dilarang untuk tujuan arus kas saat ini. ${ }^{9}$ Caluseru (2003) menyatakan pinjaman Pemerintah Daerah merupakan alat yang paling inovatif untuk peningkatan pendapatan dari investasi publik daerah di Rumania. ${ }^{10}$ Bajo (2004)

6 Pawel Swianiewicz, Local Government Borrowing: Risk and Rewards (Budapest: Open Society Institute, 2005).

7 I.G. Gibbon, Borrowing by Local Government. Public Administration, 1928, Vol 6, hlm. 00333298.

8 Zan Oplotnik dan Bostjan Brezovnik, Financing Local Government in Slovenia. Post-Communist Economies, 2004, Vol. 16, No. 4.

9 Pawel Swianiewicz, Loc.Cit., hlm. 4.

10 Gabriela Caluseru, et al., Local Government Borrowing: Regulation and Practice Country Report - Rumania, 2003, Institutal Pentra Politici Publice, Bucarest, Rumania. 
dalam penelitiannya di Kroasia menyatakan bahwa Pemerintah Daerah masih mengandalkan pinjaman bentuk-bentuk klasik untuk keamanan sumber daya dalam pembiayaan proyek-proyek modal dan ada sedikit insentif dengan menerbitkan obligasi Pemerintah Daerah. ${ }^{11}$ Faktor utama untuk meminjam masih berdasarkan kapasitas fiskal dan kemampuan untuk menjamin pembayaran pinjaman. Mahmudi (2010) menyatakan pinjaman daerah pada tingkat tertentu dapat memberikan manfaat memperbaiki struktur neraca, fiskal dan pembangunan. ${ }^{12}$ Humes IV dalam Muluk (2008) mengungkapkan bahwa pinjaman digunakan sebagai alternatif untuk membiayai investasi modal daerah seperti pembangunan jalan, jembatan, dam, gedung serba guna, fasilitas air, dan lain sebagainya. ${ }^{13}$

Di negara berkembang, karena sulitnya Pemerintah Daerah mendapat akses pasar maka Pemerintah Pusat membentuk lembaga kredit pusat yang menyediakan pinjaman kepada Pemerintah Daerah guna memperoleh modal pembangunannya. Marks dan Raman (2007) menyatakan bahwa pengawasan negara dalam praktek anggaran dan pinjaman pemerintah daerah memiliki tujuan mencegah kesulitan anggaran maupun keuangan dan membatasi penggunaan pembiayaan pinjaman hanya untuk tujuan yang sah. ${ }^{14}$ Pengawasan negara memberikan manfaat yang signifikan untuk Pemerintah Daerah dalam pengelolaan keuangannya.

\subsection{Kapasitas Fiskal Daerah}

Kapasitas fiskal daerah dapat didefinisikan sebagai kemampuan potensial dari Pemerintah Daerah untuk meningkatkan pendapatan dari sumber-sumber mereka sendiri dalam rangka membayar kebutuhan pelayanan standar barang

11 Anto Bajo. Local Government Unit Borrowing in Croatia: Opportunities and Constrains. Occasional Paper, 2004, No.20. hlm. 203-219.

12 Mahmudi, Manajemen Keuangan Daerah (Jakarta: Erlangga, 2010).

13 M.R. Khairul Muluk, Knowledge Management: Kunci Sukses Inovasi Pemerintah Daerah. Edisi Pertama (Malang: Bayumedia \& LPDFIAUnibraw, 2008).

14 Barry R. Mark dan Krishnamurthy K. Raman, State Supervision of Local Borrowing and Budgeting Practices and Municipal Net Interest Cost: an Empirical Evaluation. International Journal of Public Administration, 1987, Vol. 9, No. 4, hlm. 435-446. dan jasa masyarakat (Vazquez, 1997). ${ }^{15}$ Nagowski (2007) menyatakan bahwa kapasitas fiskal adalah pengukur kemampuan suatu daerah untuk membayar pelayanan publik yang dibutuhkan. ${ }^{16}$ Kapasitas fiskal tergantung dari kapasitas pendapatan dan kebutuhan pengeluaran suatu daerah. Baskaran dan Bigsten (2013) menyatakan konsep kapasitas fiskal mengacu pada kemampuan ekstraktif negara, yaitu, bagaimana jumlah dan jenis sumber daya negara secara teoritis bisa diekstrak dan sejauhmana ekstraksi ini berlangsung secara "efisien". Dalam Peraturan Menteri Keuangan Nomor 54/PMK.07/2014, kapasitas fiskal adalah gambaran kemampuan keuangan masing-masing daerah yang dicerminkan melalui penerimaan umum Anggaran Pendapatan dan Belanja Daerah (tidak termasuk dana alokasi khusus, dana darurat, dana pinjaman lama, dan penerimaan lain yang penggunaannya dibatasi untuk membiayai pengeluaran tertentu) untuk membiayai tugas pemerintahan setelah dikurangi belanja pegawai dan dikaitkan dengan jumlah penduduk miskin. Menurut Lewis (2003) pengukuran kapasitas fiskal daerah didasarkan pada 'surplus operasi' Pemerintah Daerah. Surplus operasi merupakan standar pengukuran untuk mengetahui kapasitas kemampuan daerah terkait dengan dana yang tersedia untuk pembayaran pinjaman daerah. Formulasi dari surplus operasi adalah jumlah seluruh penerimaan (dana bagi hasil dan pendapatan asli daerah) dikurangi belanja wajib daerah.

Kapasitas fiskal daerah tidak lepas dari peran pemerintah pusat melalui dana transfer sebagai bentuk upaya untuk pemerataan pelayanan kepada masyarakat. Pemerataan kapasitas fiskal sebagai upaya meningkatkan kemampuan pemerintah daerah untuk memberikan standar pelayanan yang sama tanpa memaksakan diferensial beban pada populasi mereka (Petchey, 2011). ${ }^{17}$ Penelitian Dahlby dan Wilson (1994) di Kanada membuktikan bahwa dana transfer sebagai pemerataan ke daerah yang optimal menyamakan biaya marjinal sosial dan meningkatkan pendapatan di semua provinsi. ${ }^{18}$

15 J. Martinez Vazquez dan L.F Jameson Boex, Loc.Cit., hlm. 3.

16 Peter Nagowski, Loc.Cit., hlm. 3.

17 Jeffrey D. Petchey, Policy Forum: State and Regional Economic Disparities Fiscal Capacity Equalisation of the Australian States. The Australian Economic Review, 2011, Vol. 44, no. 2, hlm. 207-214.

18 B. Dahlby dan L.S. Wilson, Fiscal Capacity, Tax Effort, and Optimal Equalization Grants. The Canadian Journal of Economics/ Revue 
Pada prinsipnya transfer pemerataan didasarkan pada empat formula yang berbeda yaitu (Schneider, 2002): 1) Perimbangan berdasarkan perbedaan antara kebutuhan fiskal dan kapasitas fiskal. 2) Perimbangan berdasarkan kapasitas fiskal saja (pada basis pajak), 3) Perimbangan berdasarkan indikator kebutuhan fiskal saja (biasanya terkait dengan permintaan untuk infrastruktur atau pelayanan publik), 4) Perimbangan didasarkan pada basis per kapita yang sama. ${ }^{19}$

Cara yang paling jelas meningkatkan kapasitas fiskal dengan meningkatkan pendapatan dari sumber-sumber yang ada. Pendapatan ini sebagian besar terdiri dari pajak properti, retribusi Daerah pada layanan aktivitas bisnis, dan biaya atas layanan (Ryneveld, 1990). ${ }^{20}$

Dalam Peraturan Menteri Keuangan Nomor 54/PMK.07/2014, perhitungan kapasitas fiskal daerah provinsi dan kabupaten/ kota menggunakan formulasi sebagai berikut:

$$
\begin{array}{ll}
K F= & \frac{(P A D+D B H+D A U+L P)-B P}{\text { Jumlah Penduduk Miskin }} \\
\mathrm{KF} & =\text { Kapasitas Fiskal } \\
\mathrm{PAD} & =\text { Pendapatan Asli Daerah } \\
\mathrm{DBH} & =\text { Dana Bagi Hasil } \\
\mathrm{DAU} & =\text { Dana Alokasi Umum } \\
\mathrm{LP} & =\text { Lain-lain Pendapatan yang Sah } \\
\mathrm{BP} & =\text { Belanja Pegawai }
\end{array}
$$

Menurut Undang-undang Nomor 33 tahun 2004, PAD merupakan pendapatan yang diperoleh daerah yang dipungut berdasarkan peraturan daerah sesuai dengan peraturan perundangundangan. Sumber dari PAD adalah pajak daerah, retrubusi daerah, hasil pengelolaan kekayaan daerah yang dipisahkan, dan lain-lain penerimaan yang sah (hasil penjualan kekayaan daerah yang tidak dipisahkan, jasa giro, pendapatan bunga, keuntungan selisih nilai tukar, komisi, potongan ataupun bentuk lain akibat penjualan, pengadaan barang dan jasa daerah). DBH adalah dana yang berasal dari APBN yang dialokasikan kepada daerah berdasarkan persentase untuk mendanai kebutuhan daerah dalam rangka pelaksanaan desentralisasi. Sumber DBH adalah pajak (pajak

canadienne d'Economique, 1994, Vol. 27, No. 3, hlm. 657-672.

19 Martin Schneider, Local Fiscal Equalisation Based on Fiscal Capacity: The Case of Austria. Fiscal Studies, 2002, Vol.23 No.1, hlm. 105-133.

20 Philip Van Ryneveld, Financing Local Government. Urban Forum, 1990, Vol.1, hlm. 1015-3802. penghasilan) dan sumber daya alam (kehutanan, pertambangan, perikanan, pertambangan minyak bumi, pertambangan gas bumi dan pertambangan panas bumi). DAU adalah dana yang berasal dari pendapatan APBN yang dialokasikan dengan tujuan pemerataan kemampuan keuangan antar daerah dalam rangka pelaksanaan desentralisasi. Jumlah keseluruhan DAU ditetapkan sebesar 26 persen dari pendapatan dalam negeri neto yang ditetapkan dalam APBN. Alokasi DAU tiap-tiap daerah dihitung berdasarkan celah fiskal (kebutuhan fiskal dikurangi kapasitas fiskal daerah) dan alokasi dasar (jumlah PNS daerah).

\subsection{Restrukturisasi Pinjaman}

Sesuai dengan Peraturan Menteri Keuangan Nomor 153/PMK.05/2008, pengertian restrukturisasi pinjaman Pemerintah Daerah adalah pengaturan kembali persyaratan terhadap kewajiban pinjaman Pemerintah Daerah. Beberapa bentuk restrukturisasi pinjaman, diantaranya (Sjahdeini, 1999): melakukan konversi pinjaman dengan convertible bond, penjadwalan kembali pelunasan pinjaman (rescheduling), pemberian masa tenggang (grace period), pemberian moratorium kepada debitur, persyaratan kembali perjanjian pinjaman (reconditioning), pengurangan jumlah pinjaman pokok (hair cut), pengurangan tingkat suku bunga, pengurangan jumlah bunga dan pinjaman pokok yang tertunggak, memberikan tambahan pinjaman baru, mengkonversi pinjaman dengan surat pinjaman yang dapat dipindah tangankan, menjual aktiva yang tidak produktif. ${ }^{21}$

Das (2012) mendefinisikan restrukturisasi pinjaman sebagai pertukaran instrumen pinjaman, seperti pinjaman atau obligasi, instrumen pinjaman baru atau uang tunai melalui proses hukum. ${ }^{22}$ Cruces dan Trebesch (2011) menyatakan pemberian restrukturisasi pinjaman dapat dilakukan dengan (1) memotong nilai nominal dalam persen dari semua kredit yang direstrukturisasi, dan (2) ukuran potongan pinjaman. $^{23}$

21 Sutan Remy Sjahdeini, Restrukturisasi Pinjaman dan Penyehatan Perseroan, Makalah, Magister Manajemen Universitas Sriwijaya, 1999.

22 Udair S. Das, Michael G. Papaioannou dan Cristoph Trebesh, Sovereign Debt Restructuring 1950-2010: Literatur Survey, Data, And Stilized Fact, IMF Working Paper, 2012.

23 Juan Cruces dan Christoph Trebesch, Sovereign Defaults: The Price of Haircuts, IMF Working Paper, 2010. 


\section{METODE PENELITIAN}

Penelitian ini menggunakan metode kuantitatif. Analisis data menggunakan Partial Least Square (PLS) yang menguji pengaruh kapasitas fiskal daerah dan restrukturisasi pinjaman Pemerintah Daerah terhadap kinerja pembayaran pinjaman Pemerintah Daerah. Kinerja Pembayaran Pinjaman Pemerintah Daerah adalah jumlah kewajiban pinjaman pemerintah daerah untuk masing-masing Pemerintah Daerah dengan nilai Rupiah. Kinerja pembayaran dapat diukur dari dua hal, yaitu: 1) jika dilihat secara positif, dapat diukur dari jumlah pembayaran (angsuran) yang dibayarkan masing-masing Pemerintah Daerah setiap tahun, 2) jika dilihat secara negatif, dapat diukur dari jumlah kewajiban pinjaman yang jatuh tempo setiap tahun. Kinerja pembayaran dalam penelitian ini dilihat dari jumlah kewajiban pinjaman Pemerintah Daerah. Peningkatan kinerja pembayaran diukur dengan berkurangnya jumlah kewajiban pinjaman Pemerintah Daerah.

Variabel Kapasitas Fiskal dalam penelitian ini meliputi Pendapatan Asli Daerah (PAD), Dana Bagi Hasil (DBH), Dana Alokasi Umum (DAU), Lain-lain Pendapatan Daerah yang sah (LP), belanja pegawai, dan jumlah penduduk miskin. Sedangkan variabel restrukturisasi pinjaman menggunakan data dummy berupa tahun sebelum dan sesudah kebijakan restrukturisasi dengan disertai statistik deskriptif untuk lebih menguatkan perkembangan pinjaman Pemerintah Daerah. Data dalam penelitian ini berupa data panel dari 45 Pemerintah Daerah seluruh Indonesia yang memiliki pinjaman dalam restrukturisasi. Data panel berupa: 1) data cross section yang meliputi data APBD dan realisasi APBD Pemerintah Daerah, tingkat kemiskinan daerah dan data tunggakan pinjaman jangka panjang Pemerintah Daerah seluruh Indonesia pada Direktorat Sistem Manajemen Investasi (Dit. SMI), Direktorat Jenderal Perbendaharaan, Kementerian Keuangan. 2) data time series menggunakan data tahun 20032013. Penentuan data time series untuk mengetahui perkembangan pinjaman 5 tahun sebelum kebijakan restrukturisasi yaitu tahun 2003-2007 dan perkembangan pinjaman 5 tahun sesudah kebijakan restrukturisasi yaitu tahun 2009-2013. Data time series yang digunakan hanya memasukkan data Pemerintah Daerah yang memiliki pinjaman dalam restrukturisasi. Penelitian terbatas pada pinjaman jangka panjang Pemerintah Daerah dalam restrukturisasi dan tidak termasuk pinjaman BUMD. Data panel (pooled data) yang digunakan dalam penelitian ini bersifat tidak seimbang (unbalanced) karena tidak keseluruhan data dilakukan pengujian. Penulis tidak memasukkan data pinjaman Pemerintah Daerah yang tunggakan pokoknya telah lunas dikarenakan kewajiban Pemerintah Daerah yang masih tercatat hanya tunggakan non pokok yang akan dihapuskan dan data tersebut tidak berubah sampai adanya ketetapan penghapusan atas tunggakan non pokok oleh Pemerintah.

\section{HASIL PENELITIAN}

Adanya pinjaman Pemerintah Daerah di Indonesia ditandai dengan dibentuknya Rekening Dana Investasi pada Bank Indonesia berdasarkan Keputusan Dewan Moneter Nomor 07/KEP/DEM/1971. Setelah dilimpahkan kepada Kementerian Keuangan payung hukum pengelolaan rekening mengalami pembaharuan terus menerus hingga pembaharuan terakhir melalui Keputusan Dirjen Perbendaharaan Nomor KEP-244/PB/2010 tanggal 27 Desember 2010 tentang Penetapan Rekening Dana Investasi dan Rekening Pembangunan Daerah di Bank Indonesia sebagai Rekening Penerimaan Kuasa Bendahara Umum Negara. Pengelolaan pinjaman daerah dilaksanakan oleh Dit. SMI. Selain menatausahakan pinjaman Pemerintah Daerah, Dit. SMI juga menatausahakan pinjaman kepada BUMN/BUMD. Dana pinjaman proyek dari pinjaman luar negeri sebagian disalurkan kepada beberapa Pemerintah Daerah yang membutuhkan untuk pengembangan wilayahnya dengan membuat Perjanjian Penerusan Pinjaman (Subsidiary Loan Agreement -SLA).

Dengan adanya restrukturisasi pinjaman Pemerintah Daerah tahun 2008, terdapat perubahan nilai tunggakan pokok pinjaman dari tahun 2008 sampai dengan 2012. Tunggakan pokok dapat berkurang dari Rp216.689 juta pada tahun 2008 menjadi Rp81.480 juta pada tahun 2013. Penurunan tunggakan tahun 2008 sampai tahun 2013 dapat ditampilkan sebagai berikut:

Gambar 1. Tunggakan Pokok Pinjaman 2008-2013 (dalam jutaan Rupiah)

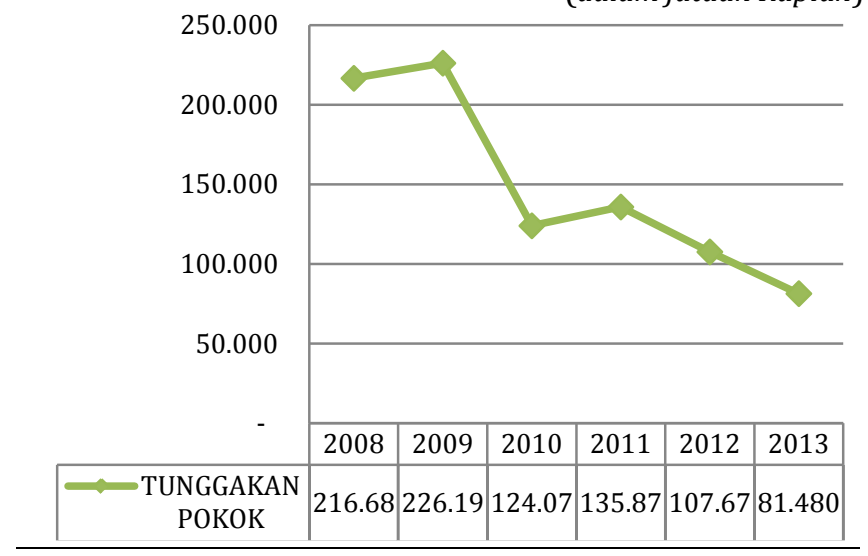

Sumber: Dit. SMI diolah (2014) 
Sampai dengan batas terakhir pengajuan restrukturisasi utang Pemerintah Daerah, yaitu 22 Oktober 2009, terdapat 48 Pemerintah Daerah yang mengajukan permohonan dan sampai dengan 30 Juni 2014 sebanyak 47 Pemerintah Daerah telah disetujui, 1 Pemerintah Daerah diantaranya disetujui tahun 2012. Persetujuan restrukturisasi utang pada periode implementasi PMK Nomor 153/PMK.05/2008 sebagaimana diubah dengan PMK Nomor 20/PMK.05/2011 yang diberikan kepada 47 Pemerintah Daerah dengan rincian sesuai gambar berikut:

Gambar 2. Persetujuan Restrukturisasi Pinjaman Pemerintah Daerah di Indonesia

(dalam jutaan Rupiah)

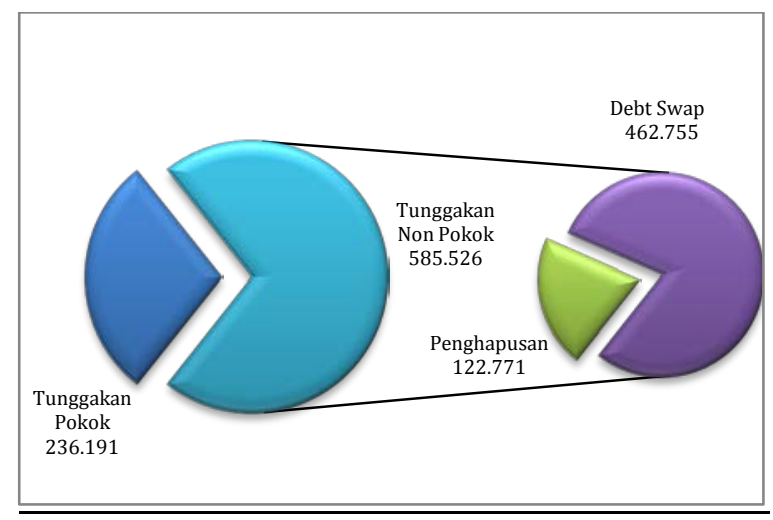

Sumber: Dit. SMI diolah (2014)

Dari gambar 2. dapat dijelaskan bahwa jumlah keseluruhan pinjaman yang direstrukturisasi sebesar Rp821.716,23 juta dengan rincian tunggakan pokok yang dijadwalkan sebesar Rp236.190,68 juta dan tunggakan non pokok sebesar Rp585.525,55 juta. Dari tunggakan non pokok yang akan dihapus, sebesar Rp462.754,91 juta dihapuskan melalui debt swap dan melalui penghapusan sebesar Rp122.770,64 juta. Penghapusan melalui debt swap ini mewajibkan Pemerintah Daerah untuk mendanai kegiatan berupa pembangunan sarana dan prasarana daerah yang dibiayai dengan belanja modal daerah yang bersumber dari APBD.

Untuk menguji model penelitian maka dilakukan uji multikolinieritas. Hasil pengujian menunjukkan bahwa semua variabel mempunyai nilai VIF yang lebih kecil dari 10, sehingga model yang terbentuk tidak mengandung gejala multikolinier.

Besarnya kontribusi kapasitas fiskal dan kebijakan restrukturisasi pinjaman terhadap kinerja pembayaran pinjaman Pemerintah Daerah dapat diketahui melalui koefisien determinasinya (adjusted $\mathrm{R}^{2}$ ) yaitu sebesar 0,469 (46,9\%). Hal ini berarti keragaman kinerja pembayaran pinjaman Pemerintah Daerah dapat dijelaskan oleh variabel PAD, BP, DAU, LP, DBH, kemiskinan, dan kebijakan restrukturisasi pinjaman sebesar 46,9\%, sedangkan sisanya sebesar 53,1\% merupakan kontribusi dari variabel lain yang tidak dibahas dalam penelitian ini.

Hasil pengujian hipotesis secara simultan menghasilkan nilai $F_{\text {hitung }}=59,961$ dengan probabilitas 0,000. Hal ini dapat dinyatakan bahwa terdapat pengaruh signifikan secara simultan (bersama-sama) variabel PAD, BP, DAU, LP, DBH, kemiskinan, dan kebijakan restrukturisasi pinjaman terhadap kinerja pembayaran pinjaman Pemerintah Daerah. Persamaan analisis PLS dari hasil pengujian adalah:

Kinerja Pembayaran $=0,261 P A D-0,251 B P+$ $0,161 D A U+0,178 L P+0,407 D B H+$

0,012 Kemiskinan - 0,159 Kebijakan Restrukturisasi

Hasil analisis pengaruh PAD terhadap kinerja pembayaran pinjaman Pemerintah Daerah menghasilkan nilai $t_{\text {hitung }}=2,798$ dengan probabilitas 0,005 . Hal ini menunjukkan bahwa terdapat pengaruh yang signifikan PAD terhadap kinerja pembayaran pinjaman Pemerintah Daerah. PAD merupakan faktor yang sangat penting dalam mengukur kemampuan dan kemandirian daerah. Dengan PAD yang tinggi berarti Pemerintah Daerah mampu mengelola potensi daerahnya dengan baik. Rata-rata persentase PAD terhadap pendapatan pada 45 Pemerintah Daerah yang memiliki restrukturisasi pinjaman selama tahun 2009-2013 masih pada kisaran 9 persen. Ini berarti Pemerintah Daerah masih memiliki peluang menggali pendapatannya dengan upaya untuk lebih kreatif dalam meningkatkan pendapatan dari potensi yang ada. Adanya Undang-undang Nomor 28 Tahun 2009 tentang Pajak Daerah dan Retribusi Daerah dapat menjadi acuan daerah untuk terus menggali PAD. Peningkatan potensi pendapatan ini dapat diwujudkan bila Pemerintah Daerah mampu menyediakan layanan publik yang dibutuhkan masyarakat sehingga masyarakat juga bersedia untuk membayar layanan publik yang disediakan. Hasil penelitian ini menguatkan Teori Barang Publik (Mangkusubroto, 2001). Tiebout (1956) dalam Jordan (2003) mengungkapkan peningkatan layanan publik daerah akan mempengaruhi jenis, ukuran, dan pertukaran kegiatan bisnis daerah dan peningkatan jumlah pembayar pajak daerah. Apabila kemampuan daerah terbatas maka Pemerintah Daerah dapat menggunakan sumber-sumber pinjaman. Dengan meningkatkan PAD maka dapat meningkatkan kinerja pembayaran pinjaman.

Hasil analisis pengaruh BP terhadap kinerja pembayaran pinjaman Pemerintah Daerah menghasilkan nilai $t_{\text {hitung }}=2,993$ dengan probabilitas 0,003. Hal ini menunjukkan bahwa terdapat pengaruh yang signifikan BP terhadap 
kinerja pembayaran pinjaman Pemerintah Daerah. Belanja pegawai merupakan faktor belanja paling utama dalam APBD. Semakin besar belanja pegawai maka akan mengurangi porsi belanja yang lain dalam APBD. Rata-rata belanja pegawai pada 45 Pemerintah Daerah yang memiliki restrukturisasi pinjaman selama tahun 2009-2013 berkisar pada 55 persen. Ini berarti lebih dari setengah pendapatan daerah digunakan untuk membiayai belanja pegawai. Penelitian Petchey (2011) menunjukkan bahwa belanja pegawai merupakan bagian dari pemenuhan standar belanja pelayanan Pemerintah Daerah. Keterbatasan anggaran ini tentu akan menimbulkan kesulitan bagi Pemerintah Daerah untuk melakukan investasi dalam jumlah besar dalam satu tahun anggaran. Efisiensi dapat dilakukan dengan pinjaman karena beban pinjaman dapat dibagi dalam beberapa tahun anggaran sehingga investasi dapat berjalan untuk peningkatan pendapatan daerah. Peningkatan pendapatan secara tidak langsung akan mengurangi persentase belanja pegawai sehingga nantinya dapat meningkatkan kinerja pembayaran pinjaman daerah.

Hasil analisis pengaruh DAU terhadap kinerja pembayaran pinjaman Pemerintah Daerah menghasilkan nilai $t_{\text {hitung }}=1.175$ dengan probabilitas 0.240. Koefisien DAU sebesar 0.161. Temuan ini menunjukkan bahwa DAU tidak berpengaruh terhadap kinerja pembayaran pinjaman. Dalam Undang-undang Nomor 33 Tahun 2004 disebutkan bahwa DAU untuk suatu daerah dialokasikan atas dasar celah fiskal dan alokasi dasar. Alokasi dasar dihitung berdasarkan jumlah gaji Pegawai Negeri Sipil Daerah. Celah fiskal dihitung berdasarkan kebutuhan fiskal daerah dikurangi dengan kapasitas fiskal daerah. Kebutuhan fiskal daerah merupakan kebutuhan pendanaan daerah untuk melaksanakan fungsi layanan dasar umum diukur dengan jumlah penduduk, luas wilayah, Indeks Kemahalan Konstruksi, Produk Domestik Regional Bruto per kapita, dan Indeks Pembangunan Manusia. Sedangkan kapasitas fiskal daerah merupakan sumber pendanaan daerah yang berasal dari PAD dan DBH.

Tidak signifikannya pengaruh DAU terhadap kinerja pembayaran pinjaman dapat dijelaskan dengan perbandingan antara pagu BP dengan jumlah alokasi DAU. Data perbandingan rata-rata persentase BP terhadap DAU terendah sebelum tahun 2008 dan sesudah tahun 2008 adalah Pemerintah Provinsi Maluku dengan rata-rata 41 persen dan 49 persen. Sedangkan persentase BP terhadap DAU terbesar sebelum tahun 2008 adalah Pemerintah Provinsi Riau dengan rata-rata 452 persen dan untuk persentase BP terhadap DAU setelah tahun 2008 adalah Pemerintah
Kabupaten Bengkalis dengan rata-rata 1006 persen. Rata-rata keseluruhan persentase data Belanja Pegawai terhadap DAU sebelum tahun 2008 adalah 85 persen dan sesudah tahun 2008 adalah 123 persen. Nilai persentase yang tinggi ini mengindikasikan bahwa pada setiap daerah, DAU merupakan komponen utama untuk pembayaran gaji pegawai sehingga sangat kecil kemungkinan bahwa DAU digunakan sebagai penjamin atas pinjaman Pemerintah Daerah.

Hasil analisis pengaruh LP terhadap kinerja pembayaran pinjaman Pemerintah Daerah menghasilkan nilai $t_{\text {hitung }}=2,141$ dengan probabilitas 0,016. Hal ini menunjukkan bahwa terdapat pengaruh yang signifikan LP terhadap kinerja pembayaran pinjaman Pemerintah Daerah. Lain-lain Pendapatan Daerah yang Sah (LP) bersumber dari hibah, dana bagi hasil pajak provinsi dan pemda lainnya, dana penyesuaian dan lain-lain. Dalam struktur APBD, LP ini tidak secara rutin diperoleh setiap daerah. Rata-rata LP diperoleh dari dana bagi hasil pajak provinsi yang meliputi pajak kendaraan bermotor, bea balik nama kendaraan bermotor, pajak bahan bakar, pajak air permukaan dan pajak rokok sedangkan Dana Bagi Hasil dari Pemda lainnya berasal dari Dana Bagi Hasil sumber daya alam. Pendapatan dari LP ini juga tidak terikat sehingga bagi daerah dapat digunakan sebagai bagian untuk meningkatkan kemampuan daerah dalam kinerja pembayaran pinjaman.

Hasil analisis pengaruh DBH terhadap kinerja pembayaran pinjaman Pemerintah Daerah menghasilkan nilai $t_{\text {hitung }}=2,653$ dengan probabilitas 0,008. Hal ini menunjukkan bahwa terdapat pengaruh yang signifikan DBH terhadap kinerja pembayaran pinjaman Pemerintah Daerah. Komponen DBH terdiri dari DBH pajak dan DBH sumber daya alam. Sejak tahun 2009 untuk bagi hasil Pajak Bumi dan Bangunan Pedesaan dan Perkotaan (PBB-P2) sudah dialihkan kepada Pemerintah Daerah yang tertuang dalam Undangundang Nomor 28 Tahun 2009 tentang Pajak Daerah dan Retribusi Daerah. Dengan adanya pengalihan ini, pengukuran DBH lebih pada bagi hasil pajak penghasilan dan sumber daya alam. Dalam Undang-undang Nomor 33 Tahun 2004 tentang Perimbangan Keuangan antara Pemerintah Pusat dan Pemerintah Daerah terdapat 7 sektor bagi hasil sesuai dengan persentase tertentu yang telah ditetapkan Pemerintah Pusat. Pemerintah Daerah yang memiliki sumber daya alam yang melimpah tentu akan memperoleh bagi hasil yang besar walaupun dalam porsi persentase bervariasi. Sedangkan daerah yang tidak memiliki sumber daya alam, akan mendapatkan dana bagi hasil dari daerah lain dalam satu provinsi secara merata untuk sektor hasil hutan (Provisi Sumber Daya Hutan - 
PSDH), tambang umum (royalty), panas bumi, minyak bumi, dan gas bumi. Jika Pemerintah Daerah memiliki DBH tinggi tentunya akan meningkatkan kinerja pembayaran pinjaman daerah.

Hasil analisis pengaruh kemiskinan terhadap kinerja pembayaran pinjaman Pemerintah Daerah menghasilkan nilai $t_{\text {hitung }}=0,149$ dengan probabilitas 0,882. Hal ini menunjukkan bahwa tidak terdapat pengaruh yang signifikan antara kemiskinan terhadap kinerja pembayaran pinjaman Pemerintah Daerah. Dalam menentukan kapasitas fiskal daerah, kemiskinan menjadi salah satu faktor yang menjadi bahan pertimbangan karena kemiskinan menjadi tanggung jawab baik Pemerintah Pusat maupun Pemerintah Daerah sesuai dengan amanat UUD 1945 bahwa fakir miskin dan anak-anak terlantar dipelihara oleh negara. Pemerintah wajib untuk dapat memberikan pelayanan kebutuhan dasar masyarakat miskin. Program pemerintah baik pusat maupun daerah yang ada untuk mengatasi kemiskinan dilaksanakan dengan beberapa hal antara lain pemberian beras bagi masyarakat miskin, kartu sehat, pendidikan gratis, dan program pemberdayaan masyarakat miskin. Program-program ini tentunya membutuhkan dana yang wajib disediakan pemerintah dan tidak dapat dialihkan untuk pengeluaran yang lain.

Hasil analisis pengaruh kebijakan restrukturisasi pinjaman terhadap kinerja pembayaran pinjaman Pemerintah Daerah menghasilkan nilai $t_{\text {hitung }}=2,883$ dengan probabilitas 0,004. Dengan kata lain, terdapat perbedaan yang signifikan kinerja pembayaran pinjaman Pemerintah Daerah antara sebelum dan sesudah adanya kebijakan restrukturisasi pinjaman. Restrukturisasi pinjaman dengan menghapuskan tunggakan non pokok dan menjadwalkan kembali tunggakan hutang pokok bagi Pemerintah Daerah menyebabkan pengurangan kewajiban jatuh tempo dan pengurangan penumpukan kewajiban pada tahun 2008 dan tahun-tahun setelahnya. Adanya restrukturisasi ini memberikan kontribusi pada perbaikan kondisi keuangan daerah dan dapat mendorong peningkatan ekonomi karena Pemerintah Daerah dapat kembali melakukan investasi dari tunggakan non pokok yang dihapuskan. Perkembangan restrukturisasi pinjaman Pemerintah Daerah dapat ditampilkan dalam gambar berikut:
Gambar 3. Perkembangan Restrukturisasi

Pinjaman Pemerintah Daerah di Indonesia

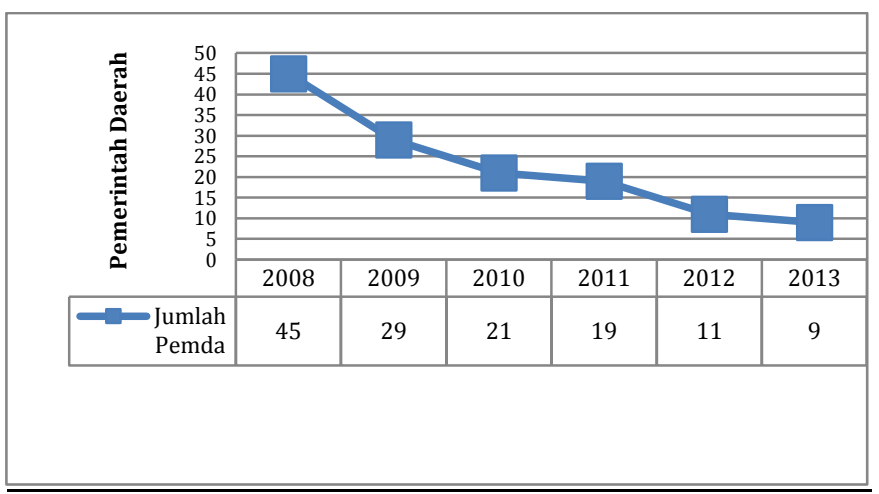

Sumber: Dit. SMI diolah (2014)

Berdasarkan gambar 3. diatas dapat dijelaskan bahwa dari 45 Pemerintah Daerah yang direstrukturisasi pada tahun 2008 memiliki indikasi yang baik terhadap penyelesaian kewajiban pinjamannya dengan adanya penurunan jumlah Pemerintah Daerah yang masih memiliki kewajiban pokok dari tahun 2008-2013. Jumlah Pemerintah Daerah yang masih memiliki kewajiban pokok tahun 2008 sebanyak 45 Pemerintah Daerah berkurang menjadi 29 Pemerintah Daerah pada tahun 2009. Ini berarti pada tahun 2009 sebanyak 16 Pemerintah Daerah melakukan percepatan pembayaran dengan melunasi kewajiban pokok yang ada. Jumlah ini mengalami penurunan menjadi 21 Pemerintah Daerah pada tahun 2010, yang berarti terdapat 8 Pemerintah Daerah yang melunasi kewajiban pokoknya. Tahun 2012 kembali menurun menjadi 11 Pemerintah Daerah karena adanya pelunasan kewajiban pokok 2 Pemerintah Daerah pada tahun 2011 dan 8 Pemerintah Daerah pada tahun 2012. Sampai dengan tahun 2013 hanya tersisa 9 Pemerintah Daerah yang masih memiliki kewajiban pokok. Dari 9 Pemerintah Daerah yang masih memiliki kewajiban pokok terdapat 3 Pemerintah Daerah dengan tingkat kewajiban terbesar dan jumlah perjanjian terbanyak yaitu Pemerintah Kota Medan, Pemerintah Kota Makassar, dan Pemerintah Kota Palembang. Banyaknya jumlah perjanjian pinjaman menjadi faktor penyelesaian kewajiban pokok. Namun secara bertahap kewajiban pinjaman 3 Pemerintah Daerah ini memiliki tren yang menurun karena adanya angsuran pembayaran kewajiban dan satu persatu perjanjian pinjaman telah dilunasi.

Restrukturisasi memberikan pengaruh yang signifikan karena adanya restrukturisasi memberikan sinyal yang baik antara niat baik dari kreditur menjadwal ulang pinjaman dan komitmen dari debitur untuk membayar dengan adanya kelonggaran yang diberikan. Bukti empiris krisis utang yang pernah terjadi pada negara berkembang seperti Argentina, Brasil, Meksiko, 
dan India juga disebabkan oleh pinjaman dari Pemerintah Daerah dan ini dapat diatasi dengan adanya restrukturisasi berupa penghapusan dan penjadwalan kembali tunggakan. Pinjaman jangka panjang yang dikelola Dit. SMI termasuk pinjaman lunak akan menjadi pinjaman berbiaya tinggi bila Pemerintah Daerah yang memiliki pinjaman mengalami gagal bayar. Hal ini dapat dilihat dari nilai tunggakan non pokok yang melebihi nilai tunggakan pokoknya.

\section{KESIMPULAN DAN SARAN}

Secara umum penelitian ini dapat disimpulkan bahwa secara simultan kapasitas fiskal daerah memengaruhi kinerja pembayaran pinjaman Pemerintah Daerah. Semakin tinggi kapasitas fiskal daerah semakin baik kinerja pembayaran pinjaman Pemerintah Daerah. Kapasitas fiskal daerah dapat dijadikan indikator bagi suatu daerah apabila akan mengadakan suatu pinjaman terkait dengan kemampuan daerah itu untuk membayar kembali pinjamannya. Hasil penelitian secara parsial dapat dijelaskan sebagai berikut:

1. PAD memengaruhi kinerja pembayaran pinjaman daerah. Semakin besar kemampuan daerah dalam menggali potensi daerahnya maka semakin besar pendapatan daerahnya dan dapat menjadi tolak ukur kemampuan daerah dalam kinerja pinjaman untuk pembangunan jangka panjang.

2. DBH memengaruhi kinerja pembayaran pinjaman Pemerintah Daerah. Suatu daerah yang memiliki DBH tinggi menunjukkan bahwa daerah itu memiliki sumber daya alam yang melimpah sehingga apabila daerah memiliki pinjaman akan memiliki kemampuan terkait dengan kinerja pembayaran pinjamannya.

3. DAU tidak memengaruhi kinerja pembayaran pinjaman daerah. Hal ini disebabkan karakteristik dalam DAU merupakan bentuk alat pemerataan ekonomi daerah dan secara umum dipersiapkan untuk membiayai belanja rutin (belanja pegawai). DAU tidak dapat dijadikan jaminan untuk mengukur kinerja pembayaran pinjaman daerah.

4. LP memengaruhi kinerja pembayaran pinjaman. Hal ini disebabkan LP tidak secara kontinu diperoleh setiap tahun dan merupakan pendapatan yang tidak terikat sehingga bagi daerah dapat digunakan sebagai bagian untuk meningkatkan kemampuan daerah dalam pembayaran pinjaman dari LP.

5. BP memengaruhi kinerja pembayaran pinjaman Pemerintah Daerah. Sifat BP yang merupakan belanja wajib dan tidak dapat ditunda menyebabkan BP harus terpenuhi terlebih dahulu sebelum Pemerintah Daerah melakukan belanja yang lain.

6. Kemiskinan tidak memengaruhi kinerja pembayaran pinjaman Pemerintah Daerah. Kemiskinan dijadikan salah satu faktor dalam pengukuran kapasitas fiskal karena penduduk miskin sesuai dengan amanat undang-undang dasar merupakan beban bagi negara maupun daerah.

7. Restrukturisasi Pinjaman memengaruhi kinerja pembayaran pinjaman. Kebijakan pemerintah berupa restrukturisasi banyak dimanfaatkan Pemerintah Daerah untuk menyelesaikan pinjamannya. Dengan penyelesaian pinjaman ini maka catatan (track record) pinjaman Pemerintah Daerah menjadi lebih baik dan dapat mengajukan pinjaman lagi berupa pinjaman jangka panjang maupun pinjaman jangka pendek.

\section{IMPLIKASI DAN KETERBATASAN}

Penelitian ini memiliki keterbatasan sehingga memungkinkan untuk dilakukan pengembangan pada penelitian-penelitian selanjutnya, yaitu:

1. Penelitian ini hanya meneliti 45 Pemerintah Daerah yang masuk dalam restrukturisasi. Penelitian selanjutnya dapat menggunakan jumlah sampel yang lebih besar untuk mendapatkan hasil generalisasi yang lebih baik.

2. Penelitian ini tidak meneliti dampak dari penghapusan tunggakan non pokok dan debt swap atas pinjaman Pemerintah Daerah yang direstrukturisasi terhadap ekonomi daerah.

\section{PENGHARGAAN (ACKNOWLEDGEMENT)}

Ucapan terima kasih kepada civitas akademika Universitas Brawijaya, keluarga besar Direktorat Jenderal Perbendaharaan dan rekanrekan yang telah memberikan kontribusi berupa sumbang saran dan kontribusi lainnya terhadap penyelesaian Karya Tulis Ilmiah ini. Penulis bertanggung jawab sepenuhnya terhadap hasil penelitian termasuk error yang kemungkinan terjadi.

\section{DAFTAR PUSTAKA (REFERENCES)}

Alm, J. \& Indrawati, S.M. (2003). Decentralization and Local Government Borrowing in Indonesia. Retrieve from google website: www.books.google.com.

Aribawa, B.D. (2005). Kapasitas Pengembalian Pinjaman Daerah dalam Pembiayaan Pembangunan Perkotaan. Tesis, Tidak Dipublikasikan, Program Pascasarjana Universitas Diponegoro Semarang. 
Bajo, A. (2004). Local Government Unit Borrowing in Croatia: Opportunities and Constrains. Occasional Paper, No.20, hlm. 203-219.

Baskaran, T. \& Bigsten, A. (2013). Fiscal Capacity and the Quality of Government in SubSaharan Africa. Jurnal of World Development, Vol. 45, hlm. 92-107.

Caluseru, G., et al. (2003). Local Government Borrowing: Regulation and Practice Country Report - Rumania. Institutal Pentra Politici Publice, Bucarest, Rumania.

Canuto, O. \& Liu, L. (2013). Until Debt Do Us Part: Subnational Debt, Insolvency, and Markets. The World Bank

Capeci, J. (1994). Local Fiscal Policies, Default Risk, and Municipal Borrowing Cost. Journal of Public Economics, Vol. 53, hlm. 73-89.

Cruces, J. \& Trebesch, C. (2010). Sovereign Defaults: The Price of Haircuts. IMF Working Paper.

Dahlby, B. \& Wilson, L.S. (1994). Fiscal Capacity, Tax Effort, and Optimal Equalization Grants. The Canadian Journal of Economics/ Revue canadienne d'Economique, Vol. 27, No. 3, hlm. 657-672.

Das, U.S., Papaioannou, M.G., \& Trebesh C. (2012). Sovereign Debt Restructuring 1950-2010: Literatur Survey, Data, and Stilized Fact. IMF Working Paper.

Elmi, B. (2002). Keuangan Pemerintah Daerah Otonom. Jakarta: Penerbit Universitas Indonesia (UI-Press).

Ghozali, I. \& Latan, H. (2012). Partial Least Squares Konsep, Teknik dan Aplikasi menggunakan Program SmartPLS 2.0 M3. Semarang: Badan Penerbit Universitas Diponegoro.

Gibbon, I.G. (1928). Borrowing by Local Government. Public Administration, Vol. 6, hlm. 0033-3298.

Hita, F.C., Orayen, R.E. \& Arzoz, P.P. (2009). Municipal Indebtedness in Navarra: The Impact of Borrowing Limits and Urban Development. Retrieve from Department of Economics Public University of Navarra, Spain website: http://www.google.com.

Kementerian Keuangan. (2014). Nota Keuangan dan Anggaran Pendapatan dan Belanja Negara Tahun 2014

Lewis, B.D. (2003). Local Borrowing and Repayment in Indonesia: Does Fiscal Capacity Matter. Jurnal of World Development, Vol. 31, No. 6, hlm. 10471063.
Mark, B.R. \& Raman, K.K. (1987). State Supervision of Local Borrowing and Budgeting Practices and Municipal Net Interest Cost: an Empirical Evaluation. International Journal of Public Administration, Vol. 9, No.4, hlm. 435-446.

Muluk, M.R.K. (2008). Knowledge Management: Kunci Sukses Inovasi Pemerintah Daerah. Edisi Pertama. Malang: Bayumedia \& LPDFIA-Unibraw.

Mulyono, I. (2007). Aspek-aspek Kuantitatif yang Memperngaruhi Kebijakan Pinjaman Daerah (Studi Kasus Kabupaten/ Kota di Propinsi Jawa Timur). TEMA, Vol. 8, No.2.

Nagowski, P. (2007). The Fiscal Capacity of New England. Policy Brief 07-4, New England Public Policy Center, Federal Reserve Bank of Boston.

Oplotnik, Z. \& Brezovnik, B. (2004). Financing Local Government in Slovenia. PostCommunist Economies, Vol. 16, No. 4.

Pasaribu, A.V. (2008). Analisis Pinjaman Daerah untuk Pembiayaan Pembangunan Pasar Kahayan Kota Palangkaraya, 2008-2027. Tesis, Tidak Dipublikasikan, Program Pascasarjana Universitas Gadjah Mada Yogyakarta.

Pascual, M., et al. (2004). Local Government Debt: An Application to the Spanish Case. Regions and Fiscal Federalism, 44rd ERSA Congress, Portugal.

Petchey, J.D. (2011). Policy Forum: State and Regional Economic Disparities Fiscal Capacity Equalisation of the Australian States. The Australian Economic Review, Vol. 44, No. 2, hlm. 207-214.

Ryneveld, P.V. (1990). Financing Local Government. Urban Forum, Vol.1.

Schneider, M. (2002). Local Fiscal Equalisation Based on Fiscal Capacity: The Case of Austria. Fiscal Studies, Vol.23, No.1, hlm. 105-133.

Sitorus, K. (2009). Analisis Pinjaman Daerah untuk Pembangunan/ Rehabilitasi Pasar di Kabupaten Dairi dalam Perspektif Kelembagaan. Tesis, Tidak Dipublikasikan. Program Pascasarjana Universitas Gadjah Mada Yogyakarta.

Sjahdeini, S.R. (1999). Restrukturisasi Pinjaman dan Penyehatan Perseroan. Makalah, Magister Manajemen Universitas Sriwijaya.

Swianiewicz, P. (2005). Local Government Borrowing: Risk and Rewards. Budapest: Open Society Institute. 
Tallesang, M. (2009). Kemampuan Keuangan Daerah dalam Melakukan Pinjaman Daerah Sebagai Alternatif Pembiayaan Pembangunan (Studi Kasus Kota Palu). Tesis, Tidak Dipublikasikan, Program Pascasarjana Universitas Brawijaya Malang.

Taufikurrohman. (2009). Determinan Kebijakan Pinjaman Daerah (Studi Kasus di Kabupaten/ Kota di Propinsi Jawa Timur). Tesis, Tidak Dipublikasikan, Program Pascasarjana Universitas Brawijaya Malang.

Vazquez, J.M. \& Boex, L.F.J. (1997). Fiscal Capacity: An Overview of Concepts and Measurement Issues and Thei Applicability in the Russian Federation. GSU Andrew Young School of Policy Studies, Working Paper, No. 97-3.

Wulandari, D. (2007). Pinjaman Daerah Sebagai Alternatif Pembiayaan Pembangunan Museum Gunungapi Merapi di Kabupaten Sleman. Tesis, Tidak Dipublikasikan, Program Pascasarjana Universitas Gadjah Mada Yogyakarta. 
Tabel 1. Statistik Deskriptif Variabel

\begin{tabular}{|l|r|r|r|r|}
\hline \multirow{2}{*}{ Uraian } & \multicolumn{5}{|c|}{ Statistik } \\
\cline { 2 - 5 } & \multicolumn{1}{|c|}{ Min } & \multicolumn{1}{c|}{ Max } & \multicolumn{1}{c|}{ Rata-Rata } & Simpangan Baku \\
\hline PAD & 2.062 & 2.210 .131 & 74.165 & 202.263 \\
\hline BP & 38.355 & 1.319 .316 & 290.607 & 222.355 \\
\hline DAU & 0 & $1.153,79$ & 329.926 & 190.362 \\
\hline LP & 0 & 495.352 & 33.685 & 58.163 \\
\hline DBH & 0 & 2.789 .962 & 109.925 & 328.305 \\
\hline Kemiskinan & 1.6 & 584.7 & 76.253 & 93.040 \\
\hline Kinerja Pembayaran & 0.01 & 151.036 & 14.510 & 27.355 \\
\hline
\end{tabular}

Sumber: Output SmartPLS 2.0

Tabel 2. Uji Multikolinieritas

\begin{tabular}{|c|c|c|}
\hline Variabel & Tolerance & VIF \\
\hline PAD & 0.891 & 1.122 \\
\hline BP & 0.889 & 1.125 \\
\hline DAU & 0.419 & 2.386 \\
\hline LP & 0.578 & 1.731 \\
\hline DBH & 0.539 & 1.854 \\
\hline Kemiskinan & 0.791 & 1.265 \\
\hline Restrukturisasi & 0.733 & 1.364 \\
\hline
\end{tabular}

Sumber: Output SmartPLS 2.0

Tabel 3. Hasil Output Path Coefficient, P-Value, F-Hitung dan Adjusted $R^{2}$

\begin{tabular}{|c|c|c|c|c|}
\hline Variabel & $\begin{array}{c}\text { Path } \\
\text { Coefficient }\end{array}$ & $\begin{array}{c}\text { Standardized } \\
\text { Coefficient }\end{array}$ & $\begin{array}{c}\text { T- } \\
\text { statistic }\end{array}$ & P-Value \\
\hline PAD & 0.318 & 0.261 & 2.798 & 0.005 \\
\hline BP & -0.274 & -0.251 & 2.993 & 0.003 \\
\hline DAU & 0.163 & 0.161 & 1.175 & 0.24 \\
\hline LP & 0.193 & 0.178 & 2.141 & 0.016 \\
\hline DBH & 0.464 & 0.407 & 2.653 & 0.008 \\
\hline Kemiskinan & 0.009 & 0.012 & 0.149 & 0.882 \\
\hline Restrukturisasi & -0.164 & -0.159 & 2.883 & 0.004 \\
\hline F-statistic & $=59.961$ & R Square $\left(R^{2}\right)$ & $=.479$ \\
\hline P-Value & $=0.000$ & Adjusted. $R^{2}$ & $=0.469$ \\
\hline
\end{tabular}

Sumber: Output SmartPLS 2.0 


\section{Gambar 1. Model Penelitian}

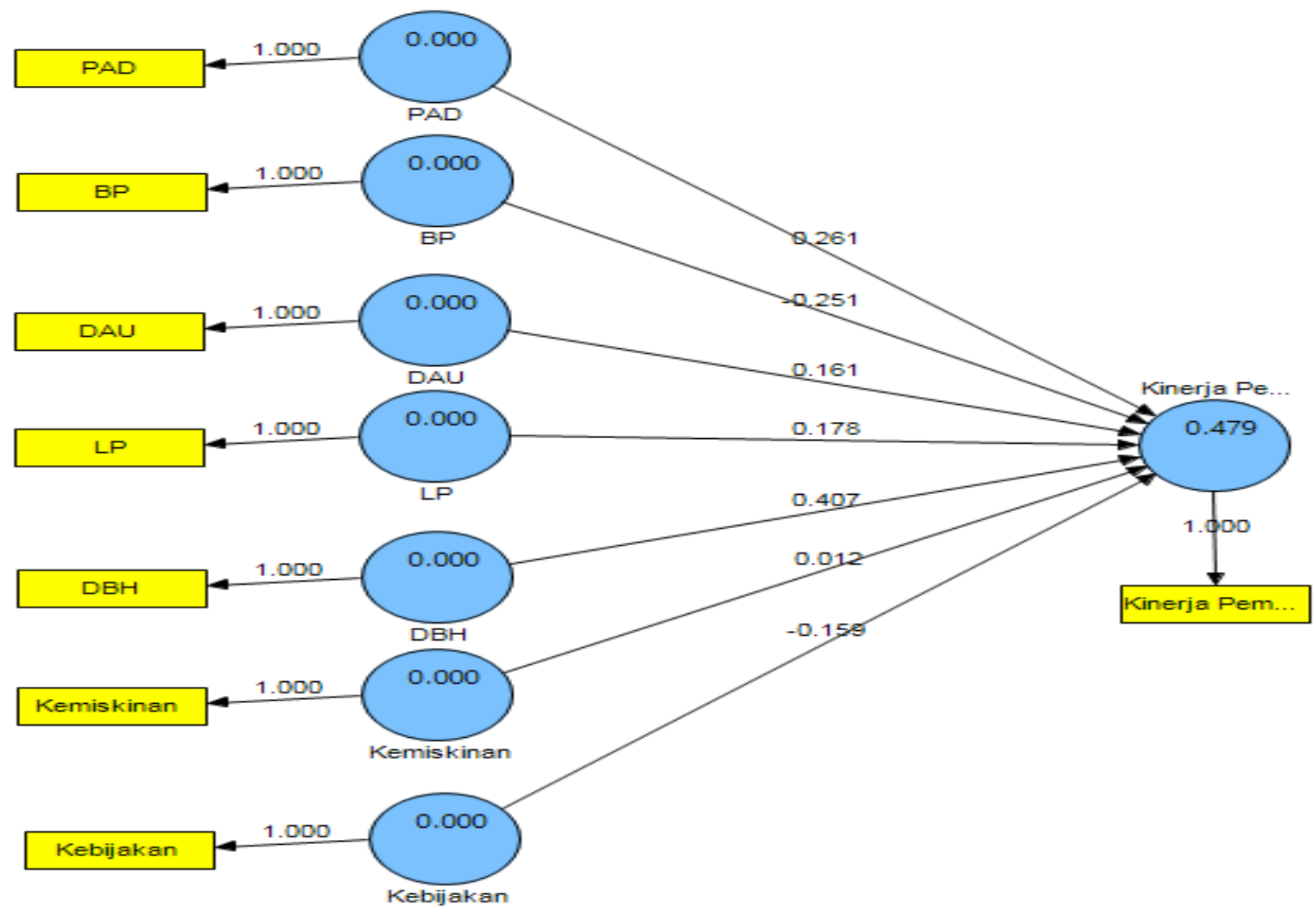

Sumber: Output SmartPLS 2.0 